\title{
Oxamniquine for treating Schistosoma mansoni infection in Sudan
}

\author{
A H S OMER
}

British Medical fournal, 1978, 2, 163-165

\section{Summary and conclusions}

The efficacy and acceptability of oral oxamniquine were assessed in Sudanese patients infected with Schistosoma mansoni. Cure rates, determined by the absence of viable eggs in the stools six months after treatment, were $94.9 \%$ in patients treated with a total of $60 \mathrm{mg} / \mathrm{kg}$, $78.8 \%$ in patients treated with $40 \mathrm{mg} / \mathrm{kg}$, and $68.9 \%$ in patients treated with $30 \mathrm{mg} / \mathrm{kg}$. All treatment regimens considerably reduced the egg count in those patients not cured.

The drug was well tolerated and the side effects were minimal and transient, the most common being dizziness. Most of the patients noticed a reddish discoloration of their urine, which was probably caused by a metabolite of the drug. In patients who received $60 \mathrm{mg} / \mathrm{kg}$ oxamniquine there were transient rises in eosinophil counts and in serum alanine aminotransferase concentrations.

Though $60 \mathrm{mg} / \mathrm{kg}$ was by far the most effective dose in terms of cure rate, egg counts were significantly reduced on all three doses. The lower doses could therefore be useful in a low-cost control programme in reducing transmission of $\mathbf{S}$ mansoni infection.

\section{Introduction}

Schistosomiasis is a major and increasing public health problem in the Sudan. The prevalence of infection has increased sharply in the past 25 years in the irrigated Gezira area of the Sudan; it is now $80^{\circ}{ }_{0}$ in children ${ }^{1}$ compared with $14^{\circ}$ in $1952 .{ }^{2}$ The recent expansion in agriculture will probably cause the spread of the disease to new provinces and resettlement areas. Nubians who were resettled in eastern Sudan after the building of the Aswan High Dam rapidly acquired Schistosoma mansoni infection, a disease unknown in their original home, and the prevalence in some regions of the resettlement area rose to $25^{\prime \prime}$ " among children within five years. ${ }^{3}$ Irrigation by pump schemes in different parts of the country has also contributed to the spread of the disease. ${ }^{4}$

Antimony treatment dominated schistosomiasis chemotherapy for over 40 years. Treatment was long term and produced many side effects. Niridazole and hycanthone emerged later, the former having the advantage of being the first successful oral treatment and the latter of giving a high cure rate with a single injection. Both, however, produce side effects, which are sometimes severe. Metrifonate emerged as another successful oral treatment with minimal side effects but was successful only in treating $S$ haematobium infestations and in the unusual presentation of $S$ mansoni in the urine. ${ }^{5}$

Preliminary work in animals has shown that oxamniquine (Vansil), a tetrahydroquinoline derivative, produces high cure

\footnotetext{
Department of Medicine and Institute of Tropical Medicine, Khartoum, Sudan
}

A H S OMER, DTM\&H, PHD, head of department and director of institute rates in $S$ mansoni infection with minimal toxicity after a short treatment period. ${ }^{6}$ : But the dose response in humans varies in different regions, and local investigations are therefore needed. ${ }^{8}$

The aim of this study was to find the optimal regimen for use in the Sudan.

\section{Patients and methods}

The clinical trial was conducted on patients reporting to the Hospital for Tropical Diseases, Sudan, in 1975-6. Patients were mainly from the Gezira irrigated area and from a recently discovered focus of the disease $25 \mathrm{~km}$ north of Khartoum. Only people with heavy and moderate Schistosoma mansoni infections (>250 eggs/g) were included. Those with severe anaemia, ascites, or poor general health; those who had received anti-bilharzial treatment within the last six months; and pregnant women were excluded.

The clinical study was divided into two stages. Stage 1 was designed to confirm efficacy of a total dose of $60 \mathrm{mg} / \mathrm{kg}$ against the Sudanese strain of $S$ mansoni, and its acceptability to patients. Seventy-three patients were treated with $15 \mathrm{mg} / \mathrm{kg}$ twice daily for two days. Parasitological assessment was by faecal egg counts using a modified Kato method. ${ }^{9}$ The average count of three stool examinations taken in the week before treatment was used as a baseline. After treatment stool samples were taken at one, three, and six months for egg counts and miracidial hatching. Haematological studies and biochemical tests of liver function were performed before treatment and on the 5th, 12 th, and 30th days after treatment. Electrocardiograms (ECGs) were recorded before treatment and one week after treatment. Patients were kept in hospital for at least five days and observed carefully for possible side effects.

Stage 2 was designed to find the lowest effective dose of oxamniquine for Sudanese $S$ mansoni. Two regimens were used: 37 patients were given a total dose of $40 \mathrm{mg} / \mathrm{kg}$ (as $20 \mathrm{mg} / \mathrm{kg}$ daily for two days); and 66 were given a total dose of $30 \mathrm{mg} / \mathrm{kg}$ (as $15 \mathrm{mg} / \mathrm{kg}$ twice daily for one day). Parasitological investigations were performed as above. Haematological and biochemical investigations were not performed.

The standard error and the degree of significance of the results were calculated by the Fisher probability method.

\section{Results}

STAGE 1

The 67 men and six women studied in the first part had an average age of 23.4 years (range 7-55) and weight of $49.3 \mathrm{~kg}$ (range 22$68.5 \mathrm{~kg}$ ). Clinical examination showed that 42 patients were in the intestinal, 14 in the hepatic, and 17 in the hepatosplenic stage of the disease.

Thirty-nine of the 73 patients $(53 \%$ ) suffered no side effects, and the reactions that did occur (table $\mathrm{I}$ ) were transient and caused minimal inconvenience. When some patients started to pass red urine on the second day of treatment specimens from 62 patients were examined for bilirubin, urobilinogen, methaemoglobin, and red blood cells, with negative results. The ECG changes were minimal. Two of the 37 patients tested showed new $\mathrm{T}$-wave inversions on the seventh day after treatment. One also suffered first-degree atrioventricular block, but no other abnormalities were detected during follow-up of the others.

Cure was defined as the absence of viable $S$ mansoni eggs in followup stool examinations. Cure rates are shown in table II calculated as a percentage of the number of patients reporting for each follow-up examination. There was a $100 \%$ cure rate one month after treatment, $98.5 \%$ at two months, and $95 \%$ at six months. All patients who were not cured showed considerable reduction in the number of eggs.

Haematological investigations showed initial (on day 5) significant increases in the packed cell volume $(P=0.05)$, the eosinophil count 
TABLE I-Side effects in oxamniquine trial, stages 1 and 2

\begin{tabular}{|c|c|c|c|c|c|c|c|c|c|c|}
\hline Dose & $\begin{array}{c}\text { No of } \\
\text { patients }\end{array}$ & Dizziness & Headache & Malaise & $\begin{array}{l}\text { Abdominal } \\
\text { pain }\end{array}$ & Diarrhoea & Itching & Vertigo & $\begin{array}{l}\text { Reddish } \\
\text { urine }\end{array}$ & Others \\
\hline $\begin{array}{l}60 \mathrm{mg} / \mathrm{kg} \\
40 \mathrm{mg} / \mathrm{kg} \\
30 \mathrm{mg} / \mathrm{kg}\end{array}$ & $\begin{array}{l}73 \\
37 \\
66\end{array}$ & $\begin{array}{r}11 \\
3 \\
2\end{array}$ & $\begin{array}{l}4 \\
2 \\
2\end{array}$ & $\begin{array}{l}5 \\
2\end{array}$ & $\begin{array}{l}7 \\
3 \\
4\end{array}$ & $\begin{array}{l}3 \\
1\end{array}$ & $\begin{array}{l}2 \\
2\end{array}$ & $\begin{array}{l}2 \\
1\end{array}$ & $\begin{array}{l}53 \\
20 \\
27\end{array}$ & $\begin{array}{l}9 \\
5 \\
7\end{array}$ \\
\hline
\end{tabular}

TABLE II-Parasitological findings in stages 1 and 2 of trial

\begin{tabular}{|c|c|c|c|c|c|c|c|c|c|c|c|c|c|c|}
\hline \multirow{2}{*}{\multicolumn{2}{|c|}{ Dose }} & \multicolumn{3}{|c|}{1 st month } & \multicolumn{3}{|c|}{ 2nd month } & \multicolumn{3}{|c|}{ 3rd month } & \multicolumn{3}{|c|}{ 6th month } & \multirow{2}{*}{$\begin{array}{c}\text { Mean " "reduction } \\
\text { in egg-count } \\
\text { at } 6 \text { months* } \\
(=\mathrm{SE} \text { of mean })\end{array}$} \\
\hline & & $\begin{array}{c}\text { No } \\
\text { studied }\end{array}$ & Cured & $\begin{array}{l}\text { Not } \\
\text { cured }\end{array}$ & $\begin{array}{c}\text { No } \\
\text { studied }\end{array}$ & Cured & $\begin{array}{l}\text { Not } \\
\text { cured }\end{array}$ & $\begin{array}{c}\text { No } \\
\text { studied }\end{array}$ & Cured & $\begin{array}{l}\text { Not } \\
\text { cured }\end{array}$ & $\begin{array}{c}\text { No } \\
\text { studied }\end{array}$ & Cured & $\begin{array}{l}\text { Not } \\
\text { cured }\end{array}$ & \\
\hline $\begin{array}{l}60 \mathrm{mg} / \mathrm{kg}(\mathrm{n}=73) \\
40 \mathrm{mg} / \mathrm{kg}(\mathrm{n}=37) \\
30 \mathrm{mg} / \mathrm{kg}(\mathrm{n}=66)\end{array}$ & $\begin{array}{l}\cdots \\
\cdots \\
\cdots\end{array}$ & $\begin{array}{l}69 \\
37 \\
66\end{array}$ & $\begin{array}{l}60(100) \\
28(76) \\
46(70)\end{array}$ & $\begin{array}{r}0 \\
9 \\
22\end{array}$ & $\begin{array}{l}67 \\
37 \\
66\end{array}$ & $\begin{array}{l}66(98.5) \\
29(78) \\
49(74)\end{array}$ & $\begin{array}{r}1 \\
8 \\
17\end{array}$ & $\begin{array}{l}64 \\
37 \\
66\end{array}$ & $\begin{array}{l}62(97) \\
29(78) \\
44(67)\end{array}$ & $\begin{array}{r}3 \\
8 \\
22\end{array}$ & $\begin{array}{l}59 \\
33 \\
58\end{array}$ & $\begin{array}{l}56(95) \\
26(79) \\
40(69)\end{array}$ & $\begin{array}{r}3 \\
7 \\
18\end{array}$ & $\begin{array}{l}93 \\
83 \div 6 \cdot 0 \\
76+7 \cdot 8\end{array}$ \\
\hline
\end{tabular}

*In patients who were not cured.

TABLE III-Haematological and biochemical values in paired comparison of pretreatment means with mean values on day 12

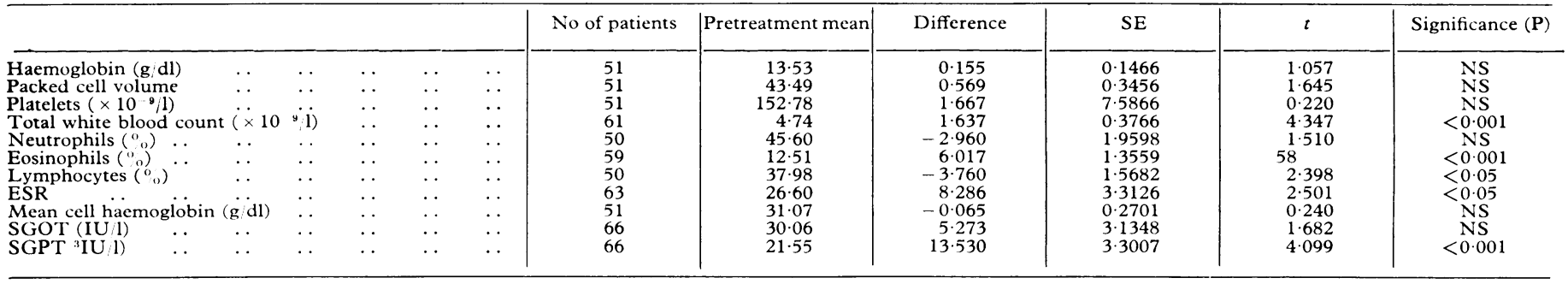

NS $=$ Not significant

$(P<0.05)$, and total white cell count $(P=0.01)$. The rise in the white cell count was due to the eosinophilia, as there was no significant increase in the other cell counts. Table III shows the difference in values between day 12 and the start of treatment. By day 12 the rise in the eosinophil count had become highly significant $(P<0 \cdot 001)$, and the erythrocyte sedimentation rate, which was not significantly increased on day 5 was significantly raised on day $12(P=0 \cdot 05)$. The rise in the total white cell count was, as before, due to the rise in the eosinophil count. This increase in the eosinophil count also lowered the percentage of lymphocytes, giving a falsely significant depression.

Of the biochemical values only serum aspartate transaminase (SGOT) concentrations were significantly raised on day $5(P<0.01)$; the increase was even more significant by day 12 (table III); $(\mathrm{P}<$ $0.001)$. There was no significant change in the serum alanine aminotransferase (SGOT) concentrations.

Haematological and biochemical values were re-estimated in 35 patients on day 30 . By then SGPT values had returned to normal (mean 22.66; difference from pretreatment value $-0.257 \pm(\mathrm{SE})$ 3.0887). Similarly, there was no significant change in the other values except in the total white cell count $(P<0.05)$, which could be explained by the highly significant rise in the eosinophil count $(P<0.01)$.

\section{STAGE 2}

Of the 37 patients ( 22 men, 15 women) who received a total dose of oxamniquine of $40 \mathrm{mg} / \mathrm{kg}, 29$ were in the intestinal stage of $S$ mansoni infection, three in the hepatic, and five in the hepatosplenic stage. Parasitological results are summarised in table II. The cure rate of $79 \%$ at six months was significantly lower $(P<0.05)$ than that in the patients who received a total dose of $60 \mathrm{mg} / \mathrm{kg}$. Those not cured showed an egg reduction rate of $83 \%$.

Of the 66 patients ( 45 men, 21 women) who received a total dose of $30 \mathrm{mg} / \mathrm{kg}$, 50 were in the intestinal, six in the hepatic, and $10 \mathrm{in}$ the hepatosplenic stage of $S$ mansoni infection. The cure rate of those reporting at six months was $68.9 \%$-again significantly lower $(\mathrm{P}<$ 0.001 ) than that in the group who received $60 \mathrm{mg} / \mathrm{kg}$ but not significantly different from that of the group who received $40 \mathrm{mg} / \mathrm{kg}$. The reduction in egg count in the remaining patients was $76 \%$, with one patient showing an actual rise in egg count.
The incidence of side effects in both groups is shown in table I, there being more side effects in those receiving the higher doses.

\section{Discussion}

The parasitological findings of this study, based on final numbers reporting, showed that oxamniquine produced a $95^{\circ}{ }_{0}$ cure rate six months after treatment when given in doses of $15 \mathrm{mg} / \mathrm{kg}$ twice daily for two days. When the total dose was reduced to $40 \mathrm{mg} / \mathrm{kg}$ and $30 \mathrm{mg} / \mathrm{kg}$ the cure rates six months after treatment dropped significantly to $79^{\circ}{ }_{0}$ and $69^{\circ}{ }_{0}$ respectively.

These findings do not agree with results in South America, where Da Silva et al ${ }^{10}$ reported a cure rate of $100 \%$ in patients who received $15 \mathrm{mg} / \mathrm{kg}$ body weight. Omgom et al ${ }^{11}$ in Uganda reported cure rates of $83 \cdot 3-91 \cdot 6^{\circ}$ o after a total dose of $40 \mathrm{mg} / \mathrm{kg}$ body weight. The morbidity of the disease in the Sudan may, however, be different from that in other regions ${ }^{1}$; indeed the disease varies in severity within the Sudan itself. Whether these differences are due to strain difference, acquired resistance to the infection, or the nutritional status of the host is not known, and is under investigation. The results of oxamniquine treatment were, however, found to be much better in animals infected with a Puerto Rican strain than in those infected with an East African strain of $S$ mansoni ${ }^{12}$ Another factor is the possibility of previous antischistosomal treatment, in which repeated and often incomplete courses of drugs are given and which may have caused cross resistance. Other factors may also affect the absorption of oxamniquine and possibly prevent curative blood concentrations from being reached. Blood concentrations of oxamniquine were investigated in patients on the low-dose and high-dose regimens in this study, and the results will be reported elsewhere.

The side effects of oxamniquine were minimal and transient. Most other workers have reported similar minimal side effects 
but their doses were lower..$^{14}$ The most common side effect was dizziness; 11 of those taking the $60 \mathrm{mg} / \mathrm{kg}$ dose complained of this symptom compared with only one of those receiving a total dose of $30 \mathrm{mg} / \mathrm{kg}$, which suggests that the symptom may be dose dependent. Abdominal pain and diarrhoea also occurred but were mild. Although these symptoms are common in patients with $S$ mansoni infection, they were probably caused, at least in part, by the drug since they occurred immediately after treatment.

Most (53) of the patients on a total dose of $60 \mathrm{mg} / \mathrm{kg}$ passed reddish urine on the second day of treatment. No other urinary abnormality was found, and a metabolite of the drug might have been responsible. I am unaware of any similar findings by other workers, but patients should be warned so that they do not become alarmed.

Eosinophilia has been reported after antichistosomal treatment with hycanthone. ${ }^{1516}$ And the eosinophil count increased significantly in the patients in this study. This may represent an immunological response to the dying worms and release of antigens, as the peak increase had occurred by day 12 . The only abnormality in liver function values was a transient rise in SGPT on the fifth and 12th days after treatment. Axton and Garnett $^{1 /}$ noticed no significant changes in the SGPT in their patients after oxamniquine treatment, while Prata et al ${ }^{13}$ reported increases in both SGOT and SGPT. Our patients showed no significant change in SGOT, but oxamniquine was given orally, and the increase in SGOT in the trial of Prata et al might be explained by the use of intramuscular injections and resulting myositis. The rise in the SGPT in our patients may suggest either a transient hepatic toxicity caused by the drug, or a shift of worms to the liver. The role played by each factor is difficult to determine.

The fact that oxamniquine was also effective in reducing the egg count in patients who were not cured may prove useful in control programmes. The percentage reduction in the number of eggs was over $90^{\prime \prime}$ " on the total dose of $60 \mathrm{mg} / \mathrm{kg}$, and there was a smaller but still significant reduction in the number of eggs on the $40 \mathrm{mg} / \mathrm{kg}$ and $30 \mathrm{mg} / \mathrm{kg}$ doses. These findings suggest that control programmes in developing countries can use lower doses, and so reduce costs, to effectively reduce transmission of $S$ mansoni infection, despite the lower cure rate.

I gratefully acknowledge the help of Dr Osborne in Nairobi and Pfizer Research Laboratories in England. I also thank the technicians and laboratory assistants of the Institute of Tropical Medicine in Khartoum for their technical help. My thanks are also due to Professor A M El Hassan for his advice and encouragement.

\section{References}

${ }^{1}$ Omer, A H S, et al, fournal of Tropical Medicine and Hygiene, 1976, 79, 151.

Greany, W H, Annals of Tropical Medicine and Parasitology, 1952, 46, 250 and 298

${ }^{3}$ Omer, A H S, PhD Thesis, University of London, 1973.

${ }^{4}$ Amin, M A, and Omer, A H S, Sudan Medical fournal, 1972, 10, 194.

${ }^{5}$ Omer, A H S, and Teesdale, C H, Annals of Tropical Medicine. In press.

'Pellegrino, J, and Katz, N, Revista do Instituto de Medicina Tropical de Săo Paulo, 1972, 14, 59 .

Foster, R, Revista do Instituto de Medicina Tropical de Săo Paulo, 1972 15,1 .

${ }^{8}$ Koura, M, et al, Fournal of the Egyptian Medical Association, 1975, 58, 287.

${ }^{9}$ Teesdale, C H, and Amin, M A, fournal of Helminothology, 1976, 50, 17.

${ }^{10} \mathrm{Da}$ Silva, et al, Revista do Instituto de Medicina Tropical de São Paulo, $1974,16,103$.

11 Ongom, V L, Kadil, A U K, and Vambora, J W, Paper presented at Cairo International Conference on Schistosomiasis, 1975.

12 Foster, R, Paper presented at the Afro-Asian Symposium on Chemotherapy for Schistosomiasis, 1971

${ }^{13}$ Prata, A, et al, Revista do Instituto de Medicina Tropical de São Paulo, 1973, 15, suppl No 1, p 47.

14 Pees, $\mathrm{P}$ H, et al, Revista do Instituto de Medicina Tropical de São Paulo, 1973, 15, suppl No 1, p 78.

${ }^{15} \mathrm{Katz}, \mathrm{N}$, et al, American fournal of Tropical Medicine and Hygiene, 1968, $17,743$.

16 Omer, A H S, et al, fournal of Tropical Medicine and Hygiene, 1972, 75, 165.

${ }^{17}$ Axton, J H M, and Garnett, P A, South African Medical Fournal, 1976, $\mathbf{5 0 ,} 1051$.

\title{
Autoimmunity in juvenile diabetics and their families
}

\author{
G F BOTTAZZO, J I MANN, MARGARET THOROGOOD, J D BAUM， DEBORAH DONIACH
}

British Medical fournal, 1978, 2, 165-168

\section{Summary and conclusions}

Pancreatic islet cell, thyroid, and gastric antibodies were studied in 116 young insulin-dependent diabetics and 257 relatives. Seventy-four per cent of the diabetics studied within three months of diagnosis had islet-cell antibodies but only $20 \%$ of those studied three years or more after diagnosis. Persistence of these antibodies was associated with a high prevalence of thyrogastric autoimmunity, which suggests that some cases have an aetiology similar

Department of Immunology, Middlesex Hospital

G F BOTTAZZO, MD, lecturer

DEBORAH DONIACH, MD, FRCP, professor

Department of Social and Community Medicine, University of Oxford

J I MANN, DM, PHD, lecturer

MARGARET THOROGOOD, BSC, research assistant

Department of Paediatrics, University of Oxford

J D BAUM, MD, FRCP, clinical reader to that of "polyendocrine" autoimmune disease. Retinopathy or nephropathy, or both, was present in 10 diabetics, who were all members of "autoimmune" families, in which one or more members had organ-specific antibodies. Nine of the 10 healthy relatives with islet-cell antibodies and all families with more than one diabetic were also in this autoimmune group.

These data suggest that an autoimmune factor may contribute to juvenile diabetes and that such autoimmune diabetes has a tendency to run in families and may be more likely to cause complications.

\section{Introduction}

Autoantibodies to pancreatic islet cells were first described in patients with diabetes mellitus who also had polyendocrine autoimmune diseases. ${ }^{12}$ Islet-cell antibodies were subsequently found in $60-85^{\circ} \%$ of newly diagnosed patients with juvenile diabetes. ${ }^{3}$ In these patients the antibodies are strongly associated with diabetes of short duration, and two to five years after diagnosis their prevalence has fallen to less than $20 \%{ }^{4-6}$ Whether an association exists between islet-cell and thyrogastric antibodies is unclear, ${ }^{4}$ and there are few data on thyrogastric 